own medicines. The great bulk of the people cannot afford to pay a medical man's fee and at the same time a chemist's bill, as they would have to do under the new Act. The consequence would be that the great majority of the people would be either prescribed for by the chemists or use the prescription of a friend or fly to the different quack advertisements which abound in all our local papers and may even be found in the leading London " dailies."

When I came to this country there was far more prescribing done by the chemists than by the medical man, but by perseverance, hard work, and by charging very moderate fees this has considerably improved but will soon revert to the old order of things if the Act passes in its proposed form. To me, as an example, the subject is a very serious one, for I cannot retrench. As the practice is so widely scattered I am compelled to keep three horses and a coachman. I have also to pay $\$ 47$ per annum for rent for the simple reason that I cannot get a suitable house, with stables, for less. I am able to pay my way as it is but cannot put anything by for my old age. 1 pay $£ 4710 s$. yearly premium for insurance on my own life and that of $\mathrm{my}$ wife, and this is all the provision $I$ am able to make for $m y$ family. It seems clear to me if this new Act passes in its present form that $I$ and thousands of other country practitioners will be simply ruined. Our work is hard and often very anxious in its nature and now our anxieties are added to by this harassing legislation. I fail to see what harm I do in dispensing my own medicines and $I$ have the comtort of feeling that I get the best of drugs for my patients.

$$
\text { I am, Sirs, yours faithfully, }
$$

Jan. 28th, 1904

M.R.C.S, L.S.A

\section{THE INQUEST ON WHITAKER WRIGHT.}

\section{To the Editors of THE LANCET.}

SIRs, - If it be allowable to reopen discussion on this sad case I should like to say that $I$ am not alone in thinking the evidence adduced at the inquest held by Mr. Coroner Troutbeck (as reported in the Standard and the Globe newspapers) singularly inconclusive and quite inadequate to justify such an assertion as that made by the coroner himself--namely, that it was " absolutely certain beyond all possibility of doubt that the deceased took his own life." So far as can be judged from the published reports at least five persons were present for some minutes preceding the death, one or two being medical men, yet failed to detect any but natural causes of the occurrence. Surely the length of time which had elapsed after the deceased's return from the lavatory, where, on the theory of suicide by poison, the fatal dose was probably taken, would be sufficient to allow of its impregnating the breath with the distinctive odour. Yet the acting house physician of King's College Hospital, who particularly investigated this possibility, say": "His breath smelt of spirits but there was no smell of poison at all." Four other persons similarly failed to detect any peculiarity in this respect.

The necropsy, regarding which Dr. Freyberger gave evidence, did not take place until 21 hours after the death, and this is a very important point. For although the odour of prussic acid is a valuable test up to 12 hours after death it is not reliable later. Some of the organs, especially the brain, emit a similar odour where there is no suspicion of poison; and certainly the evidence of one man, however eminent, is not sufficient to establish the possibility that the odour of prussic acid, which was markedly absent during several minutes prior to the death and for some hours afterwards (as we are left to infer), should become a "penetrating smell" given off by "every organ of the body" so long after as 21 hours. At any rate, the nose is not of itself an adequate witness. Yet the only other criteria afforded by Dr. Freyberger are the bluish tint of the body and the fluidity of the blood, which are neither separately nor together distinctive. The majority of the pathological signs adduced are consonant with death from syncope due to heart failure as the result of natural causes, especially as accelerated by mental shock. No mention was made by any witness of the peculiar "cry" uttered by the majority of victims to prussic acid, the deceased did not fall as if shot, nor does he appear to have been convulsed or to have had relaxation of the sphincters (as in more than 50 per cent. of cases). The corrosion of the mucous membrane, adducer as found chiefly at the back of the tongue and in the stomach, is difficult to explain in the absence of any sign of acute pain manifested during life. Cyanide of potassium has an alkaline reaction and is not markedly caustic. But it rapidly deliquesces on exposure, giving off fumes of prussic acid as soon as moistened, making it difficult to understand how it could have remained any time on the tongue without becoming noticeable by the bystanders. There is, moreover, no evidence of the vehicle in which it would be necessary to preserve it prior to its being used.

Whitaker Wright was singularly reticent as to any intention to commit suicide. In fact, supposing he did take his own life, he seems to have been at some pains to throw people off the scent. The revolver at full-cock, with ball cartridge in every chamber and none fired, may be ranked with the at first suspected tabloid; but it is remarkable that the revolver was not found by the first searcher (who appeared to ransack every pocket), but came so readily to the hand of the coroner's officer. It is surprising that the knife, which also was found, failed to be adduced as evidence of intention. Mining engineers and many rich men carry the former as a weapon of defence. It is not clear that the revolver had a special pocket made for it in Wright's case. But it is easy to understand that the habit which he had contracted in America would not readily be given up in England, where he became a far more tempting bait to the footpad and burglar.

That Whitaker Wright had had a fatty and dilated heart is a fact of prime importance and this was established (or confirmed) by the post-mortem examination. I incline to consider the judgment of the five persons who were present before death and who attributed it to natural causes as by no means upset by the further evidence submitted to the coroner. I have given evidence in many cases of various kinds before no less than five different coroners during the last 40 years, but I cannot recall a single case in which any of the five coroners was satisfied with nose-evidence or in which I expected him to be.

Kingston-on-Thames, Feb. 1st, 1904.

I am, Sirs, yours faithfully,

D. BIDDLE, M. R.C.S. Eng.

\section{To the Editors of THE LANCET.}

SIRS, - On Tuesday, Jan. 26th, I was called in to attend Whitaker Wright at the time of his death and I naturally expected to receive an intimation as to the time and place of the necropsy. On Wednesday at 1.45 P.M. as I had received no such information I telephoned to Mr. Troutbeck who referred me to Dr. Freyberger, adding that the necropsy was probably already completed or at any rate still in progress. I can quite understand that the demands on the coroner's time may be very great, but at the same time I cannot but feel that it is in the interest of the public as well as due to our profession that the courtesy should be extended to us of inviting the medical man present at the death scene to be present at the post-mortem examination. I am, Sirs, yours faithfully,

King's College Hospital, Feb. 1st, $1904 . \quad$ OurVer ATKEY.

*** Mr. Atkey ought to have been present at the necropsy, of course.-ED. L.

\section{THE SANATORIUM TREATMENT OF CON- SUMPTION : ARE WE ON THE RIGHT TACK?}

To the Editors of THE LANCET.

SIRs,--There are 67 institutions in the United Kingdom given over to the treatment of tuberculosis. Let us say for (exaggerated) argument's sake these could receive 12,000 cases-of course they could not or anything like it, but let us put it at that. There are architects, builders, expensive sites, ornate hospitals, highly paid secretaries, chapels, chaplains, and all the usual details of hospital construction and maintenance in the charitable financial foreshadowing of the near future. Meanwhile there are the downs unused, the roof garden is neglected, the cheap and useless (now) agricultural land is ignored, and the camp of huts on those downs is never considered. We want 100,000 huts and 100,000 roof gardens. We do not want beautiful buildings on expensive sites but moveable camps on land of no agricultural value. We are not seeking to stay a transient epidemic ; we are striving to eradicate the most devastating scourge of the human race. I read the other day of a new hospital the chapel of which was to cost $£ 20,000$. But, Sirs, the chapel for these afflicted people should be where the 
Sermon on the Mount was preached and in the full eye of the healing "wind of God." We are simply canonising expensive inefficiency by inaugurating fresh hospital buildings.-I am, Sirs, yours faithfully,

GEORGE H. R. DABBS, M.D. Aberd.

Austin Friars, E.C., Jan. 20th, 1904.

\section{THE POINT OF PRIMARY GONORRHCFAL INFECTION IN THE FEMALE. \\ To the Editors of THE LANCET.}

SIRS, - The letter on this subject by Dr. J. H. Arton, published in THE LANCET of Jan. 16th, p. 190, deals with a matter of great importance and one on which misconception is probably rife. Whether Dr. Arton is or is not correct in supposing that in the female the cervical canal is the usual seat of primary infection in gonorrhoea. this much is certain, that vaginitis of any severity is an altogether exceptional result of gonorrhoeal infection in adult women and yet it is probable that most men engaged in private practice regard vaginitis as the specific criterion of gonorrhœea. Recent authorities, doubtless, inculcate other views. Herman, ${ }^{1}$ for instance, writes: "The gonococcus is short-lived and easily killed; hence it is only a passing guest in the vagina. It lingers longest in the urethra; probably in the glands of the floor of the canal near the meatus; next longest in the cervical canal. Hence you will find it in the vagina only when the disease is acute and pus abundant." Again, Muir and Ritchie in their "Manual of Bacteriology," second edition, 1899, state: "In the disease in the female gono. cocci are almost invariably present in the urethra, the situation affected next in frequency being the cervix uteri. They do not appear to infect the lining epithelium of the vagina of the adult unless some other abnormal condition be present, but they do so in the gonorrhoeal vulvo-vaginitis of young subjects."

But while gynæcologists, bacteriologists, and those whose duty involves the regular examination of prostitutes have correct views of the disease I think there can be little doubt that a large proportion of general practitioners are still under the influence of the erroneus doctrine tanght in the medical schools and reiterated in text-books until a quite recent date that vaginitis, of ten brief in duration and trifling in severity, is the principal characteristic of gonorrhoea in the female. And yet it is precisely in general practice that, as Dr. Arton indicates, so much might be done to prevent gonorrhceal infection and to lessen the disastrous consequences of the disease. The existence of latent gonorrhœe in the male has recently attracted much attention. No less attention should be given to the true nature of gonorrhoeal infection in the female which in private practice is, in nine cases out of ten, a sequel of the said latent gonorrhœa in the male and is further, as Dr. Arton rightly insists, the major source of a considerable number of the diseases peculiar to women. Apart even from the much greater frequency of the disorder there seems considerable evidence in favour of the view that gonorrhœa is a greater scourge of the human race even than syphilis. I am, Sirs, yours faithfully, Alderney, C.I., Jan. 25th, 1904. M. EDen PaUl.

\section{CARBON MONOXIDE POISONING BY THE INHALATION OF CIGARETTE SMOKE.}

\section{To the Editors of THE LANOET.}

SIRS,- In papers read some years ago before the Bolton and District Medical Society and the Lancashire and Cheshire branch of the British Medical Association I drew attention to, and described, some work I had done on this subject at the suggestion of Mr. Gibson Dyson, $\mathrm{Ph}$. D. It was shown that the presence of carbonic oxide gas could be demonstrated in tobacco smoke by several simple experiments and also analyses proved that smoke from cigarettes contains less carbon monoxide than eitcer that obtained from pipes or cigars. Notwithstanding it was pointed out that the habit of inbalation rendered the cigarette the most dangerous form in which tobacco could be enjoyed. Only by inhalation could the contained carbon monoside come in contact with the blood; the resulting carboxyhæmoglobin owing to its great stability would give an ever-increasing load to be pumped through the body, whilst the heart,

Diseases of Women, first edition, 1893. together with the rest of the tissues, was suffering from a decreased or decreasing supply of normal blood.

It was suggested that such a condition would tend to produce many of the symptoms usually associated with cigarette smoking-notably anæmia, malnutrition, diminished growth, and loss of energy the result of malnutrition of the nerve centres. It was also pointed out that the connexion of carbonic oxide with the evils attending the habitual inhalation of cigarette smoke hitherto had been overlooked and it was further suggested that the enormous amount of damage inflicted by this vice on the younger members of the community constituted a national danger and that some means should be adopted to minimise or to put an end to it. I am, Sirs, yours faithfully,

Bolton, Jan. 26th, 1904. J. HILTON Thompson, M.D. Vict.

\section{THE MEDICAL DEFENCE UNION.}

\section{To the Editors of THE LANCET}

SIRS,-In your able and instructive comment upon the action, Salisbury $v$. Gould, you made the statement that the Public Authorities Protection Act pleaded technically in addition to the evidence for the defence did not prevent Mr. Gould from being exposed to the anxiety and the expense entailed by an action persisted in until the jury refused to hear any more of it. It is quite true that the Public Authorities Protection Act did not so relieve Mr. Gould, but the Medical Defence Union, of which association he was a member, clearly did. To quote from a letter of Mr. Gould which I have before me in which he writes: "I was relieved not only of all trouble and anxiety but of very great expense, having only to go into the witness box and give my evidence. I cannot conceive how any registered medical practitioner can be so foolish as not to avail himself of the insurance afforded to all members of the Medical Defence Union." I am sure you will be willing to allow me to make this as an additional report to your article in your issue of Jan. 30th.

$$
\text { I am, Sirs, yours faithfully, }
$$

\section{A GEORGE BATEMAN,}

Trafalgar-square, W.C., Jan. 29th, 1904.

* * We have much pleasure in publishing Dr. Bateman's letter. Mr. Gould, since the appearance of our article, has written to us in much the same terms of his gratitude to the Medical Defence Union.-WD. L.

\section{TREATMENT OF DIABETES MELLITUS.} To the Editors of THE LANCET.

SIRS, - Will you kindly permit me to remark that I have read with much interest the clinical lecture on the treatment of diabetes mellitus by Dr. R. T. Williamson in THE LiANCET of Jan. 23rd, $p$ 213. In the treatment of the disease with drugs Dr. Williamson gives the preference to salicylate of sodium and aspirin. I have not had much experience of aspirin, but $I$ have been prescribing salicylate of sodium in diabetes for nearly 30 years and with so much satisfaction that I consider it my "official" remedy for the disease. I sometimes combine ergot with it, and I have the notes of cases written as far back as 1877 in which I found this combination most beneficial. We have many remedies for diabetes but, unfortunately, no specific. We have few specific remedies for any disease, with the exception, perhaps, of arsenic for pemphigus, balsam of Peru for scabies, iodide of potassium for tertiary syphilis, quinine for ague, and bromide of potassium for epilepsy.

After all, the great difficulty in the treatment of diabetes is the aietary. Most of the articles of food in present use are so unsavoury that patients soon loathe them. A Isle" might occasionally be given with impunity ; it is rather appetising and $I$ find that a meal or two is relished by most patients. The principal ingredient of it is fibrin procured from peeled, grated, raw potatoes from which for this spesial purpose the starch is abstracted and the fibrin only is retained. To this are added salt, eggs, some condiment, and sometimes a little flour. The mass is made into cakes and fried in a quantity of butter. I am sure that the readers of THE LANCET will mentally thank Dr. Williamson for his able lecture on that perplexing disease diabetes.

I am, Sirs, yours faithfully, William O'NeilL, M.D. Aberd., M.R.C.P. Lond. Lincoln, Jan. 30th, 1904 